\title{
THE ESTABLISHMENT OF CO-OPERATION WITH SPE- CIAL REFERENCE TO EXPERIENCES IN BURMA ${ }^{1]}$
}

\section{H. J. FRIETEMA}

We all know that for several reasons the governments of economically less developed countries pay much attention nowadays to co-operation and that the U.N.O. spends many millions of dollars in giving Technical Assistance in this field.

Reason number one is the very fact that people are poor in those countries. The poorer the population and the bigger the differences in the average income between the various classes of the population, the more the government is obliged and forced to step in and to play an active rôle in the economic and social field, obliged in a moral way and forced in a political manner. The philosophical, moral, economic and social way of thinking now is fundamentally different from what it has been during the nineteenth century. As KEYNES immediately after the first world-war made clear in his famous booklet "The end of laissez-faire", the "laissez-faire" system had to be substituted by governmental interference. In other words: the general idea about the task of the government has completely changed.

A second reason for promoting co-ops may be still more important. The man in the street in Calcutta and the rice-producer in the Irrawaddy-valley in Burma are not only poor, they are economically spoken dependent on other people in an apalling way. This is especially the case as regards the average farmer in the Far East : by far the majority of the population of those countries .is engaged in agriculture. "The man in the street" is the farmer and he often lives in difficult circumstances.

In the first place the landtenure system in various underdeveloped countries is such that the landowners are leaving their tenants too small an income to run their farm properly.

Moreover, the farmer is dependent on the dealer who buys his rice and who supplies him with what he wants for producing on his farm. He is also dependent on the man who is willing to lend him money. In most cases the credit-supplier is the dealer.

Accordingly, the more dependent the farmer in the under-developed countries is, the more it is up to the government to support him, to tell him what he should do to improve his social and economic position and to assist him in this respect in every possible way.

As a third reason can be mentioned the fact that since more than half a century co-operation in Europe has proved to be of the greatest value to the farmers who used to be poor and dependent and who were far less educated than they are now. As an example of what can be done to raise the social and economic status of the people, not only the agricultural co-operation should be mentioned, but also the consumers' co-operative movement, which especially in Great Britain and Scandinavia reached similar results on behalf of the industrial workers.

And finally there is the argument that co-operation means practical lessons

1) Received for publication May 24, 1953. 
in self-help and in democracy. It means that people are building themselves an organisation, are bound to be active in having general meetings, in appointing boards of directors, in stating whether their boards are running the co-op in the way they like and in doing this, people are educating themselves gradually. Also in this respect the history of co-operative activity by European farmers and industrial workers is highly valuable.

Although for all those reasons it seems attractive to have co-ops established in the under-developed countries, one should at first try to answer the question: Why are people poor in those countries?

The standard of living of any nation is depending on the productivity of human labour. Differences in density of population and the fact that various nations are of a more or less agricultural character are important in this respect, but they are not at all decisive. The average income of the inhabitants of the Netherlands is far higher than that of Burma, although the density of population in Holland is nearly 9 times as high as in Burma. The average standard of living in Great-Britain is considerably lower than in NewZealand, although Great-Britain is an industrial country whereas New-Zealand is an agricultural country and the density of population amounts for GreatBritain to 206 per $\mathrm{km}^{2}$, for New-Zealand to only 7 per $\mathrm{km}^{2}$. In Europe the standard of living as an average is lower than in the United States. All those differences in the national income per inhabitant are the result of differences in productivity of human labour and so one must state that people in those Far-Eastern countries are poor because their productivity of labour is very low indeed.

When we are confining ourselves to the agricultural activity in various countries the differences in productivity of human labour are still far more striking. The famous Australian economist ColIv ClARK, who made an investigation in this field, states that in Europe as an average their are 8.35 men tilling one square $\mathrm{km}$ of Standard Farm Land (to obtain this unit he converts the area of land by certain measures, such as: fertility, humidity, temperature etc.). Within Europe, however, there are striking differences : in Belgium the density of agrarian working population is 17.90 pro $\mathrm{km}^{2}$ S.F.L. and in the Netherlands 17.00 ; in Great-Britain, however, this figure amounts only to 5.0. For the U.S.A. Colin CLARK finds a density of working population in the agrarian field of 1.87 pro $\mathrm{km}^{2}$ S.F.L. and in New Zealand this figure is still lower, being only 0.54 . As a very contrast India shows a density of 26.8 pro $\mathrm{km}^{2}$ S.F.L. and in China this amounts to 40.80 , whereas for Egypt there is an even still higher density, namely of 74.44 males engaged pro $\mathrm{km}^{2}$ S.F.L. From this it is clear that in countries like India, China and Egypt there is far too much labour in relation to the available area of land. Colin Clark concludes that in Egypt the farmer has only 115 days full time work a year; for China this figure amounts to 200 days. In China even $1 / 5$ th of the agricultural population could be dispensed with whithout any consequences for agricultural production as a whole.

Converting the net-production pro head of the males engaged in agriculture by using a certain standard (International Unit) CoLIN CLARK comes to even more striking differences. I mention as the greatest contrast in this respect, that in China an average production of $46 \mathrm{I} . \mathrm{U}$. pro man/year seems to be normal, whereas this figure is for New Zealand 2.006 ! The average produc- 
tion of I.U. pro man/year in Europe is 234 ; for the United States of America this is 623.

This low productivity in the agricultural field is specially due to the following facts:

a farmers in those countries are producing just one type of product (rice, most for their own subsistence).

As a consequence they have no work at all to do during the time the paddy - after having been planted - is growing. Then they have simply to wait and they just wait, not doing any work during this time.

Even when the Eastern farmer would have a crop twice a year, a lot of his time would remain unproductive. A higher productivity of labour could be obtained by producing a greater variety of products. In this respect I am thinking of the production of groundnuts, sugarcane, tea, coffee, rubber, jute, pepper, bananas, citrus-fruits.

b in some of those countries the density of population, combined with its agricultural character, results in holdings, which are far too small to have a high degree of productivity. Moreover by the system of inheritance one holding may be split in so many small pieces of land that productivity is bound to be still lower.

c the way of farming in under-developed countries is completely out of date, the yield per acre being far lower than could be reached by making use of modern methods of cultivation.

As regards this last remark, I hope you will not misunderstand me: the standard of living is dependent on the productivity of human labour. Therefore the average yield of one unit of land may be of significance, but this is not so under every circumstance. In the U.S.A. the yield per acre is far lower than in Europe; yet the standard of living of the U.S.A.-farmer is higher than of his European colleague. This is to be explained by the fact that in the U.S.A. there is much more land and capital available in relation to human labour; therefore labour-saving methods are more used in the U.S.A. than in our part of the world. This is partly a result of mental differences; the American way of thinking is far more concentrated on increasing productivity and on productivity of human labour specially.

In the Far-East conditions in general are not at all favourable for putting the idea of promoting productivity in front of everything. Taking into consideration the surplus of labour in under-developed countries, it is clear, that any increase in production per acre results in an increase in productivity of human labour and in a rise in the general standard of living. This, however, does not mean, that the governments of the under-developed countries should confine themselves to increasing agricultural production only, for a real solution of the problem of productivity demands at the same time creating new possibilities for employment for the surplus of agricultural population by developing industry.

In trying to find out what is the very aim of promoting co-operation in the Far-East in general and in Burma in particular we should be aware of the fact that the word co-operation has a complicated meaning. The pioneers of Rochdale wanted "to create a self-supporting home-colony and to arrange 
the power of production, distribution, education and government" and until more recent times there are still authors (GIDE, Lavergne, Laserre, WebB, FAUQUET), who are stressing the point that the ultimate aim of the consumers' co-operative movement is the creation of a co-operative society, being something just in between capitalism and communism. On the other side agricultural co-ops have been founded for special purposes like better prices for agricultural products, lower prices and a better quality for farmers' requisites, being means to correct unfavourable circumstances as to the market position of the farmers and not as a purpose to alter the fundamental basis of economic and social society as such.

This includes that before all a reasonable answer should be given to the question as to what is the aim of promoting co-operation. As to Burma this is not at all clear. Although in a private discussion a Burmese Minister told me that Burma wanted co-operation in order to get a co-operative society, the co-operative law in this country gives the impression to be just a "normal" law, stating as an aim for co-operative activity the raising of the standard of living of the poor and dependent part of the population.

The conditions for the foundation and for the development of various types of co-ops are different. There are more difficulties for big industrial plants, requiring heavy investments and a high degree of managerial skill, than for simple supply co-ops which in general are far easier to be managed. But most important is, of course, the answer to the question as to what type of co-op contributes most to the ultimate aim of raising the standard of living. It is therefore essential to select carefully the types of co-ops which should be promoted in the first place. The importance of a good choice could be illustrated by imagining the promotion of a type of co-op which aims at the supply of agricultural machines to farmers in a district, which is characterized by plenty of human labour available. In this case the use of labour-saving machinery of course would not contribute to a higher standard of living.

Very important is also that the type of co-op that is strongly promoted by the government has success. For this success will influence favourably the public sympathy and the chances of the co-ops in general.

Whatever be the demand for various types of co-ops and whatever be the conditions for the development of co-ops, they cannot prosper unless :

a members should believe in the aim the co-op is striving at;

b members should be able to think "in the long run" taking sacrifices to-day in order to get benefits in the future;

c members should be able to run their co-ops by means of boards and presidents appointed and controlled by the general meeting.

In general the circumstances in the Far-East are difficult as regards the conditions mentioned.

d moreover, there is the fact that the farmer in the Far-East as far as he is producing for the market, is dependent on the local dealer;

e another bottle-neck is the lack of credit; every co-op, small or big, needs a working capital before it can start its business;

$\mathrm{f}$ the farmer in those countries is illiterate, which means that the propaganda should be done verbally and - just on account of his illiterateness the farmer generally is suspicious as regards recommendations which are 
made on his behalf by officials whom he does not know at all. It should be mentioned especially that in this field the importance of co-operative activity should be stressed, for it is to be understood that the co-ops want to serve the permanent interest of their members and by doing this, co-ops in general are marked by a strong activity in recommending their members to improve their way of farming in every possible respect. Farmers in Europe are far more influenced as regards their standard of farming by the educational work which has been done by the co-ops than by the information which is given by the government or by private companies.

All that has been said so far has been of a rather general character and should be seen as a background against which the promotion of co-operative activity in Burma can be projected.

Referring particularly now to Burma I may point out that I have been invited personally in the summer of 1950 by the Prime Minister, the Hon. THAKIN Nu, during his stay in our country at that time. I have been in Burma from the beginning of August till the midst of September 1950 as a private adviser to the Burmese government, having nothing to do with any international organisation specialising on technical assistance to under-developed countries. To avoid misunderstanding, I am not at all an expert as to tropical agriculture, neither in a theoretical nor in a practical way.

Burma is a country considerably larger than France. Its population however is less than 19 millions. The density of population, therefore, is far smaller than in Southern China, India, Pakistan and on Java.

Burma is a rich country, that is to say: might be a rich country. There is a plenty of good soil available for agricultural production and the climate is favourable. Moreover the soil contains many valuable minerals, such as oil, iron, copper, zinc, lead, gold and wolfram. Industry, however, is still of an elementary character.

Burma has suffered terribly from the war and from the Japanese occupation. Since the war the major problem has been to get peace in the country itself. There is a kind of civil war going on which consumes about $60 \%$ of the national budget. Burma is an independent nation since 1948.

About $3 / 4$ of the population is engaged in agriculture, which means that agricultural production is the basis of the national income. The most important export products are rice and timber. The export after the war, however, is much lower than was the case before. As to timber this is due to the fact that the most important regions for forestry are inaccessible as a consequence of the civil war whereas transport conditions are poor. As regards rice, immediately after the war there was a scarcity of bullocks whilst part of the agricultural population went to the cities in order to be protected against the insurgents. Although there are plenty of bullocks now and although most farmers have returned to their farms, rice-production is still smaller than before the war.

Agricultural production is one-sided, rice being the principle product, and is concentrated on soil which is irrigated. A greater variety of products is essential for getting a higher productivity of labour. Production of groundnuts, beans and peas (especially soy-beans), sugarcane, cotton, jute and fruits should be extended and much more cattle should be held.

Agriculture is not only one-sided, the standard of farming is very old260 
fashioned. This means that introduction of modern methods should be promoted strongly and special attention should be given to an increase of the yield per acre by using better seeds. Moreover the total area of soil suitable for production should be extended by a better and more extensive irrigation system.

Before the war the Burmese government tried to supply the farmers with credit in order to make it possible for them to have their farms better managed. During several years large amounts of money have been distributed for this purpose amongst the farmers, but the results of this governmental activity have been very poor indeed. I have been asked to analyse this problem and I came to the conclusion that two big mistakes had been made in this respect:

In the first place the credit had been given independently of its destination. This means that the government failed to make the condition that credit could be got only in case it would be used for productive purposes. As a matter of fact practically all the money the farmers got in this way has been spent in buying consumptive goods. Secondly there has been no auditing at all regarding the distribution of credit, with the result that the effect of this activity has been disappointing. In this respect it should be stated that the government underpays its officials with the result that the quality of some of them is not up to a reasonable standard.

As a consequence of the much lower exports of rice and timber, imports are restricted by means of a quota-system. Every importer is allowed to import only with a licence, on the basis of which he can import certain quantities of goods. When the government of Burma decided to promote co-operation strongly, existing co-ops were treated preferentially as regards those quota for importing goods such as condensed milk, sugar, clothing and some more articles. The number of articles being subject to import licences is very big indeed.

When I visited several local co-ops in Rangoon in order to get an idea of the existing co-operative activity the presidents of those co-ops did not stop persuading me how strongly they were in favour of the policy of the government as to the promotion of co-operation. Soon it became clear to me that many of the co-ops I visited have been founded and are run by local shopkeepers who, after their co-ops had been registered by the government, got additional licences for importing goods. I perceived that the registration of co-ops in Burma was effectuated automatically in case the rules of the co-ops proved to be in accordance with the law and the definition in the law was of a quite general character.

I was also struck by the fact that the local shopkeepers used their co-ops as a means to get bigger profits by trying to sell their condensed milk and other imported goods at the highest possible prices. On the other hand, by getting import-licences, they were enabled to pay for the import the same prices as the private importers did from whom they had to buy before they founded their co-ops. In other words : by means of founding a co-op those shopkeepers made higher profits at the cost of the ultimate consumer.

This, of course, has little to do with co-operation as we understand it and I advised the Burmese government to decide which type of co-op should be supported. I asked the government to decide whether it was the intention to strenghten the position of the ultimate consumer or of the shopkeeper. One more remark could be made as to those co-ops of shopkeepers. Although the 
law on co-operatives in Burma states that the distribution of the profits amongst the members should be in accordance with their turnover, the law makes it possible to pay a rather high interest on the capital invested. It is quite to be understood that the co-ops founded by shopkeepers tried to divide their profits on the basis of the capital invested of the members and as a matter of fact the interest paid was in most cases far higher than the dividend paid on the turnover.

In general I got the impression that most co-ops, including consumers co-ops. wanted to make high profits and to pay high dividends to their members and as a matter of fact $I$ found that the rapid development of the co-operative movement in Burma was principally based on this "dividend hunting". Founding co-operatives on this basis is dangerous in more than one respect. It is clear that in most cases there is no idealism at all. But no co-operative movement can be successful unless people are working together for realizing an idealistic aim. This means that the growth of co-ops should be gradual, because in the first phase only a small number of people will be real co-operators. Therefore a co-op is much stronger if it has only a small number of members who are prepared to stick to the principles under all circumstances than a co-op, which has many members accepting the co-op only as long as they profit from it.

As a consequence of the lack of a real co-operative ideal the financial situation of the co-ops in Burma is not at all satisfactory. General conditions have been favourable until now, but as soon as a depression might come in the future, the reserves of the co-ops will prove to be far too small.

The strongest development of the co-operative movement in Burma has been in the field of consumers' co-ops and of co-ops of shopkeepers. Besides, quite a number of producers' co-ops have been founded in Burma, members of which are weavers, umbrella-makers and other handicrafts. In my opinion, however, especially farmers' co-ops should be promoted.

Already I stated the agricultural character of Burma and the need of raising the agricultural production. The significance of farmers' co-ops in Europe is very big indeed; it is based on two principles.

The first is that the co-ops are strengthening the weak economic position of the farmers in the market. When there are no farmers' co-ops the farmer as a rule is far too much dependent on those who are buying his products and on those who are supplying him with farmers requities and with credit.

The second principle is the educational work which is done by the co-ops on behalf of their members in order to raise their standard of living.

When traveling in Burma $I$ have been lecturing all over the country and such meetings were attended by all government officials and by other important people in the districts. At those lectures I always concentrated on one aim : to make the best people enthusiastic for what can be achieved in a co-operative way. In order to make my audience feel what could be reached by founding co-ops I have been picturing the results of two types of co-ops in my own country, namely the health-co-operative and the co-op for marketing eggs.

As to the first I focussed the attention of my audience on the bad standard of health of the rural population in our country 50 till 80 years ago. At that time conditions in Holland were not much better than they are now in the Far-East. The rural population suffered from many diseases. The rate of infant 
mortality was very high. The reasons are well-known now : babies were treated in the way grandmothers did ; the diet consisted of the same food the grandfather thought the family should eat. In short, people had not the slightest idea about hygienic conditions and about a well balanced diet. In those days doctors were scarce in the villages of our country. Some far-seeing people who wanted these conditions improved took the initiative to form co-operatives for this purpose. These co-operatives are of a very simple character and structure. They are unions of practically the whole population of the villages. As to the financing of those unions, the members are classified on the board's decision of their paying capacity. This money is used for the payment of a trained nurse and for the purchase of such articles that are useful for sick people. The members of this type of co-operative, which is very popular in our country, are entitled to call for the services of the nurse and to make use of those articles without any further payment and at any time.

The nurse is the good friend of all the people in the village. Of course she cannot do what only the doctors can do, but she is the medical adviser of the village and she does a lot of educational work. This work requires imagination, perseverance, patience and a strong personality. Above all it requires idealism and social spirit.

The result of this work in our country has been miraculous. The death rate in Holland, especially the rate of infant mortality, is lower than anywhere else in the world. It is true that other causes, apart from this type of co-operatives, contributed to this important improvement in the well-being of our people such as housing, running water, general education and others. But I am convinced that the innfluence of village health-co-ops is apt to be underestimated.

The second illustration which I gave to my audience concerns the co-op for marketing eggs. Some 75 years ago farmers in Holland did not pay much attention to the production of eggs. They kept chickens as Burmese farmers do now. The eggs were small and the average production was about 40 to 50 per hen in a year. Irregularly the farmer sold his eggs to the dealer, who knew far more about the prices of eggs than the farmers did and who did not pay the eggs according to their quality.

Some leading people in the village (the schoolmaster, the elders, some wellto-do farmers) however, decided that something should be done to improve the way in which eggs were sold. They thought it essential for the farmers to found a co-operative society to sell the eggs for the members. Two principles have to be accepted. The first is that the members should send their eggs to the co-operative regardless of the price the local dealer offers for them. The second principle is that the eggs should be sold in a co-operative way, which means that after the costs of running the co-op are deducted from its grossincome, the balance of the sale proceeds should be distributed amongst the members according to the quantity and to the quality of the eggs they have sent to the co-operative.

Although in the beginning the co-op was boycotted by the private dealers and many difficulties had to be overcome, this type of co-op succeeded and extended its business. The various village co-ops co-operated in founding a national co-op for selling their eggs and gradually wholesale business in eggs was done. They learned to judge the market better and they found even a 
larger market by exporting. They learned to put eggs in cold stores in order to stabilise the prices of the eggs all the year round.

During all this time the co-op did a great deal of educational work. They taught the farmers how to select chickens for reproduction purposes in order to get an ever increasing egg production pro animal and a larger size of eggs. The co-ops taught the members also how to improve the chicken feed and how to have better housing for their poultry. Both are important to prevent diseases. In short: the co-ops taught the farmers everything about poultryfarming and their knowledge of this would have been much less had there been no co-ops.

As to the results of this type of co-op in our country, our eggs now are as an average about twice as big as they were some 75 years ago. The average number of eggs produced pro animal has amounted to 175 , being as a national average the highest figure in the world. Moreover to-day eggs are one of the most important export-articles of Holland although the consumption of eggs per capita by Dutch consumers nowadays is much larger than in olden times and although the population has nearly doubled during the last 75 years ${ }^{1}$ ).

The founding of such a co-op might be of the greatest importance for under-developed countries, preassuming that there are possibilities for selling the eggs. By promoting poultry-farming superfluous labour can be made productive in a very easy way and a higher standard of living can be reached. In order to succeed the co-op will have to do a lot of educational work, but it seems worth while when we notice that on the poor soil in the southern and eastern part of our country farmers' income nowadays consists for $1 / 3$ of the results of poultry-farming.

From those illustrations we can learn some lessons. In the first place, in our country - as in some more European countries - there was no governmentactivity at all in the field of co-operation. Although it is to be accepted that in the under-developed countries the government takes the initiative in promoting the co-operative movement the co-ops will only succeed when people are active and interested themselves.

As a second fact we establish that in our country we did not wait to start co-operatives until each farmer, especially the one who needed it most, was convinced of the value of co-ops. Some leading men who had more vision than the average farmer took the initiative. They did not do this for their private gain but in the interests of the masses. In other words : a strongly developed social feeling of the higher classes in the village is a vital condition for making co-operatives successful.

The third lesson is that once co-ops have been founded members should be convinced that the co-operative principles should be kept strictly. Members should also understand that the effect of the co-operative can only be felt in the long run and that it is essential that they should not deal with private traders where the co-ops can do the same job.

I do not know whether in Burma I made sufficiently enthusiastic one or two people who might be the future leaders of the co-operative movement

1) All this cannot be attributed to the co-ops only, but it is without any doubt that the co-operatives have made an important contribution to these results. 
in that country. For the greater part the development of co-operation in countries like Germany and Holland has been the result of the activity of one or two strong personalities who were the leaders of an idealistic movement. Co-operation in Europe has been one of the means - and a very important one - to raise the standard of living and to bring more justice. For the underdeveloped countries it may even be more. There is in Burma as far as I can see a kind of vacuum in an idealistic respect and a sound co-operative movement may offer possibilities to fill this gap. Much depends on the influence of the real leaders of the nation and much depends too on the real strength of the co-ops themselves.

The bottle-necks are manifold and what is needed most is education. Education in three directions :

1 to make people conscious of what co-operation can be;

2 to use co-op as a practical lesson in selfhelp and in democracy;

3 to learn people to accept small sacrifices to-day in order to get larger advantages to-morrow.

\title{
LiteratuRE
}

Colin Clark, The world's capacity to feed and clothe itself, "The way ahead", Vol. II no. 2.

\section{AGRICULTURE AND TECHNICAL ASSISTANCE IN PAKISTAN ${ }^{1}$ )}

\author{
Ir. G. C. W. CHR. TERGAST
}

As agricultural economist $I$ have been for fourteen and a half months in Pakistan on an assignment of F.A.O.'s Expanded Technical Assistance Program. During this period I visited several parts of the rural areas, conferred with many authorities of the central and provincial governments, private persons and several international experts of various agencies on technical assistance assignments in Pakistan, all directly or indirectly working on agriculture and its connected problems. All this gave me an excellent opportunity to study Pakistan's agricultural development and to understand its needs and requirements.

Agriculture in Pakistan has large opportunities for further development, but under the existing circumstances and conditions there are several hampering factors which will take much time to overcome, when realizing the possibilities in a short couple of years.

Before going into these problems in some more detail I will try to give in a short survey an idea about Pakistan of today with its agriculture and the many problems connected.

Pakistan got its independency on August 14, 1947. On that date the former British Indian subcontinent was divided into two independent countries : 1 . the Dominion of Pakistan including those regions with a majority of Moslim population, and 2. the Republic of India, called Bharat by Pakistani, where

1) Received for publication May 24, 1953. 